
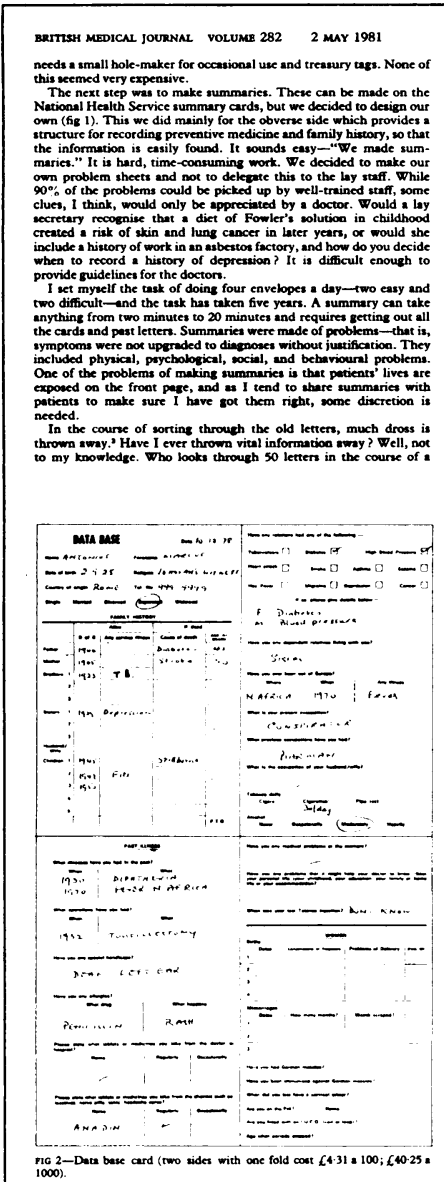

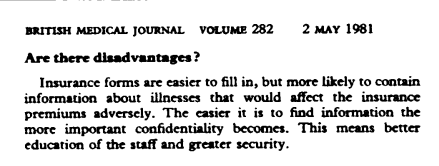

Has it all been worth while?

Yes, without a doubt. A glance at the problem shect and the
family history does orientate me before I see the parient reminds me to ask about problems other then that presented,
and occasionally we pick up important lapsed follow-ups

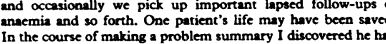

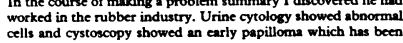
cells and cystoscopy showed an early papilloma which has been
"cured ".
I hope the quality of my problem solving is helped by the

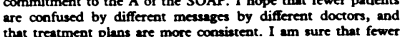
that treatment plans are more consisisent. I am sure that fewer
prescriptions go awry and that patients are reviewed more

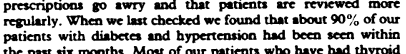

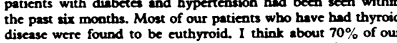
women patients who might conceive are known to be immunce
rubella. I cerraininy check more random blood pressures. Yes again, it is worth while, and I would nor go beck to being witho
structured notes. But it has been a strugegle because time had

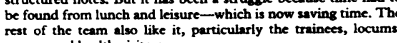
What of the future?

I suppose we must atrempt $100 \%$ completion of the summaries
and $100 \%$ covernge of aspects of preventive medicine. We

\title{
A night at the opera: RSM meeting on delivering primary
} care in inner cities
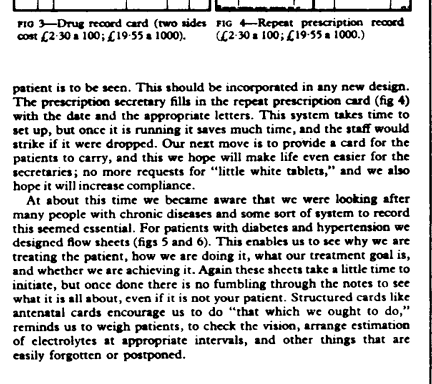

SUE BURKRART

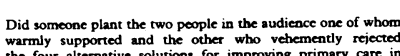

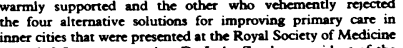
recenty? 1 suspect not, but Dr Luke Zander, president of
section of

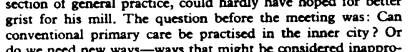

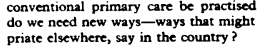

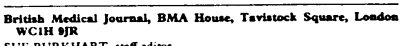
SUE BURRHART, saf editor
141

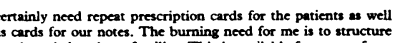

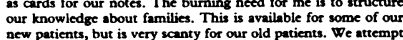

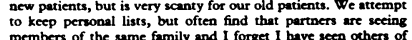

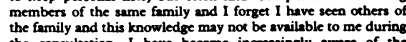

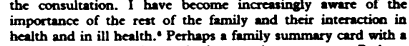
health and in ill health. Perhaps a family summary card with
family tree kept in the mother's notes is once answer. Perthepe

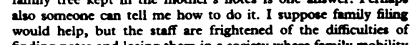
is increased.
I a gree with Dr Weed that we need good records to practive the way and became more important than the patient. Now feel that they are the essential background to efficient, caring
general prectice. They cercainly make life easier for me, and I

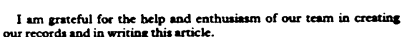

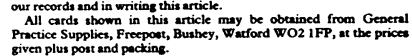

References

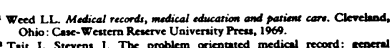

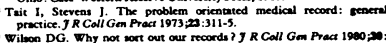

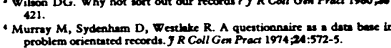

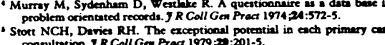

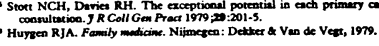

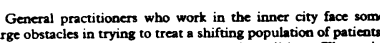

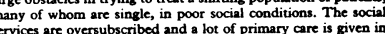

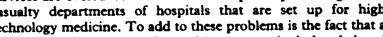

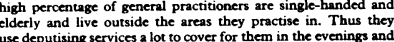
on wectededi
With his reality for background, the question was addressced by a generel prectitioner in private prectice in Loddon, $D$ d

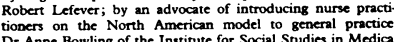

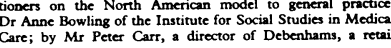
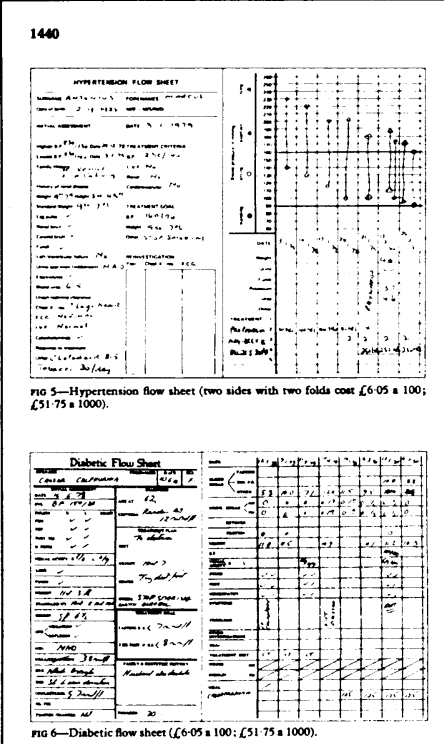

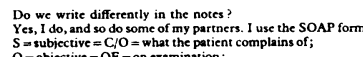

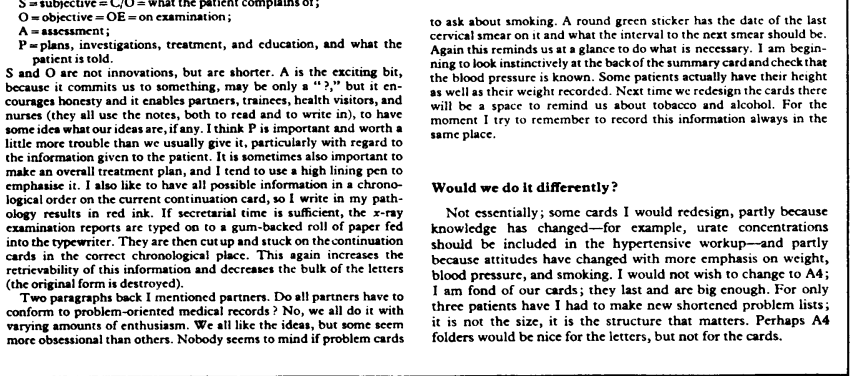

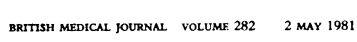

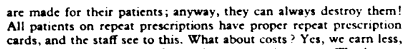

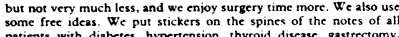

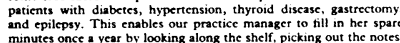

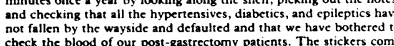

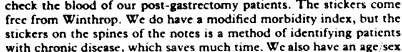

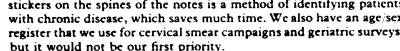

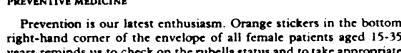

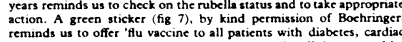

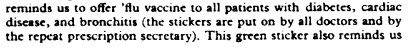

\begin{tabular}{|c|c|}
\hline \multicolumn{2}{|c|}{ Fu VACCINE } \\
\hline 1980 & 1985 \\
\hline 1981 & 1986 \\
\hline 1982 & 1987 \\
\hline 1983 & 1988 \\
\hline 1984 & 1969 \\
\hline \multicolumn{2}{|c|}{ Smoking yes 100} \\
\hline
\end{tabular}

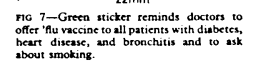

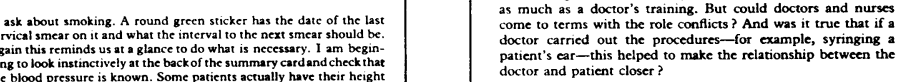

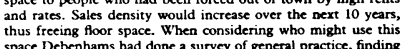

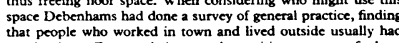

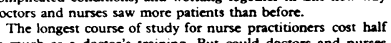

Luring general practitioners back to tow

Debenhams department store wanted to renat some of its flocen
space to popple who had bern forced out

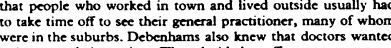

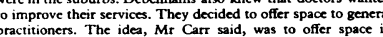

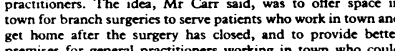

BRTIISH MEDICLL JOURNAL VOLUME $282 \quad 2 \max 1981$ not afford to improvec their surgeries. Debenhams had never
intended to offer medical services to their customers - but hey

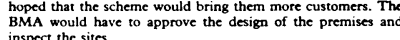

Running a general practitioner deputising service that had

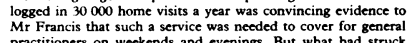

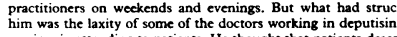

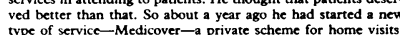

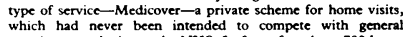

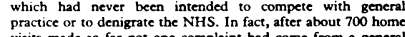

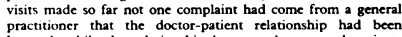
harmed, while the relationsthip berwecen doctors and patient

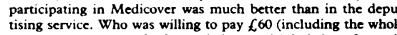

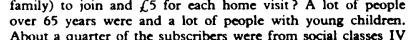

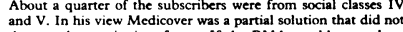
damage che continuity of care. If the BMA would meet them
Medicover would be willing to discuss threc things: notifying

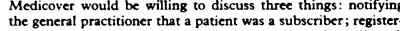

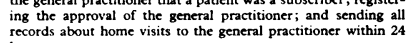

Although the audience on the whole thought that these four

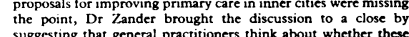

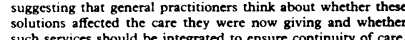
such services should be integrated to ensurec continuiry of carce
Buu is changing the way primary are is provided in the inne

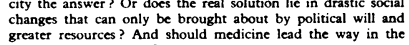

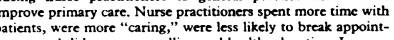

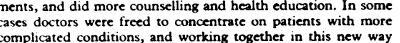
(a)

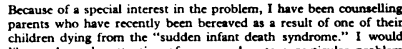

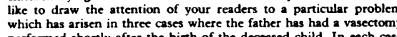

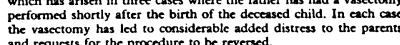

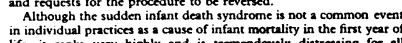

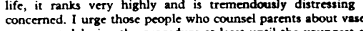

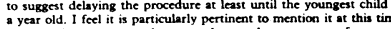

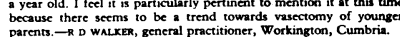

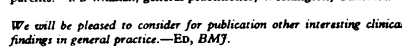

(1) 